\title{
Trends in Rice-Based Farming Systems in the Mekong Delta
}

\author{
Nguyen Van Kien, Nguyen Hoang Han, and Rob Cramb
}

\section{INTRODUCTION}

In this and the next three chapters, the focus shifts to the Mekong Delta in Vietnam, which accounts for $15 \%$ of the Lower Mekong Basin by area and $27 \%$ of the total paddy area but in 2015 produced $48 \%$ of the Basin's total rice output and about $60 \%$ of its rice exports (Fig. 17.1). Thus, it is indisputably the "overflowing rice basket" of the region. It is also overflowing in the sense that much of the Delta is naturally flooded in the wet season and has been subjected to major hydraulic works to permit inten-

N. Van Kien $(\bowtie)$

An Giang University, Long Xuyen, Vietnam

Fenner School of Environment and Society, Australian National University,

Canberra, ACT, Australia

e-mail: nvkien@agu.edu.vn

N. Hoang Han

Charles Sturt University, Wagga Wagga, NSW, Australia

R. Cramb

School of Agriculture and Food Sciences, University of Queensland, St Lucia, QLD, Australia

e-mail: r.cramb@uq.edu.au

(C) The Author(s) 2020

R. Cramb (ed.), White Gold: The Commercialisation of Rice

Farming in the Lower Mekong Basin, https://doi.org/10.1007/978-981-15-0998-8_17 


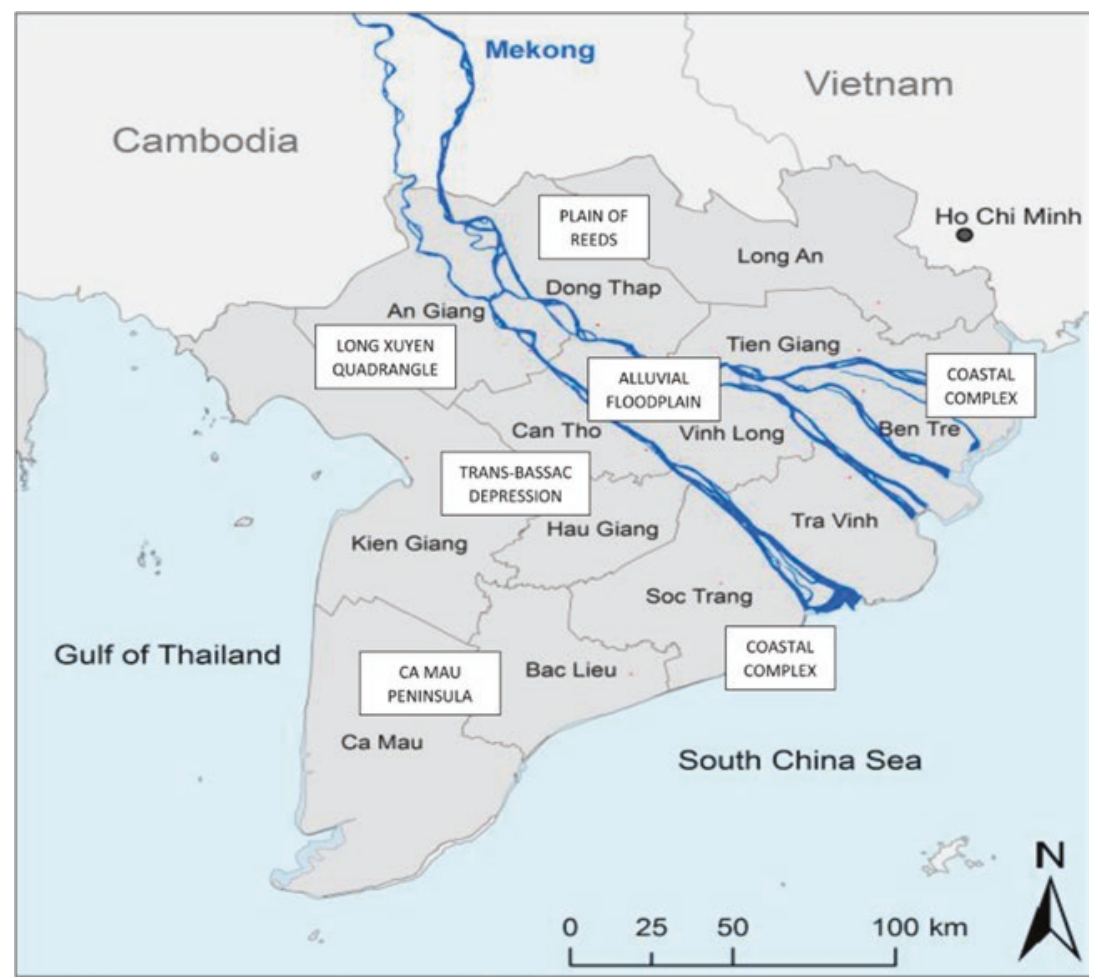

Fig. 17.1 Mekong Delta showing provinces and agro-ecological zones. (Source: Base map by CartoGIS Services, College of Asia and the Pacific, Australian National University)

sive rice farming throughout the year. It is also under threat of sea-level rise. This chapter reviews the trends in rice-based farming systems in the Delta as a whole while subsequent chapters report on field studies in An Giang and Hau Giang Provinces in the upper and middle Delta, respectively. These studies examined the domestic rice value chain from input suppliers to consumers (Chap. 18) and the cross-border trade from Cambodia (Chap. 19). Chapter 20 examines the more specialised crossborder trade in sticky rice between Savannakhet Province in Central Laos and Quang Tri Province in the North Central Coast region of Vietnam (thus complementing the analysis of rice marketing in Savannakhet in Chap. 9). 


\section{Geography of the Mekong Delta}

As a geographical unit, the Mekong Delta comprises a triangle of almost $50,000 \mathrm{~km}^{2}$ of mostly fertile alluvial and marine deposits extending from Phnom Penh in south-eastern Cambodia through southern Vietnam to the South China Sea and the Gulf of Thailand. About $39,000 \mathrm{~km}^{2}$ or $78 \%$ of the total area lies within Vietnam. We use the term "Mekong Delta" in this chapter to refer to the Vietnam portion of the Delta. In this portion, canal construction, first for transport, then for irrigation and drainage, has been undertaken over the past two centuries, accelerating under French rule in 1910-1930 and again since the end of the Indochina War in 1975 (White 2002). The Delta now has over $10,000 \mathrm{~km}$ of canals and 20,000 km of dykes, profoundly altering the hydrology and agroecosystems of the region. About $90 \%$ of the cropland is now irrigated.

The climate of the Mekong Delta is similar to that of the Lower Mekong as a whole - a tropical monsoonal climate with distinct wet and dry seasons (Fig. 17.2). The wet season occurs from June to October, when monthly rainfall averages over $200 \mathrm{~mm}$, and the dry season from December to April. Variation in temperature combined with the seasonality of rainfall gives rise to three rice-cropping seasons: (1) a cooler wet season from July to October (the main or "autumn crop"); (2) a cooler, late wet/early dry

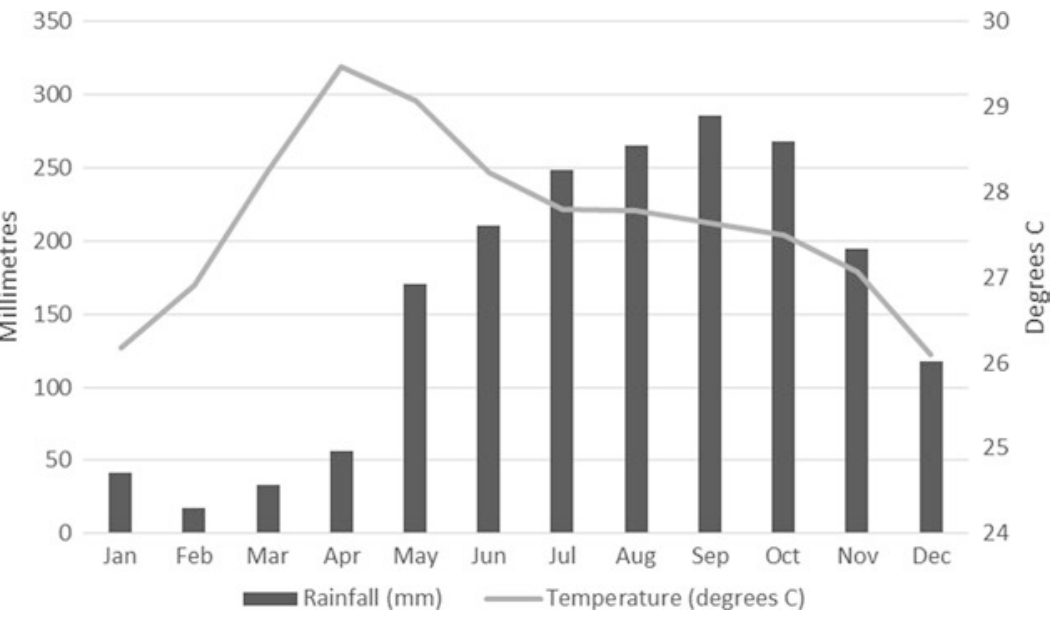

Fig. 17.2 Mean monthly rainfall and temperature at Can Tho. (Source: Climatic Research Unit, University of East Anglia) 
season from November to February (the "winter crop"); and (3) a hot, early wet season from March to June (the "spring crop").

Wet-season flooding has been the dominant constraint in the upper Delta, with flood depths of more than four metres, while saline intrusion in the dry season is the major factor affecting land use in the lower Delta, limiting rice production to one crop per year (White 2002). Fertile alluvial soils make up about 30\% of the Delta, mainly along the banks of the Mekong and Bassac Rivers, but acid sulphate soils occur in broad depressions over $40 \%$ of the area-about half the Delta is subject to saline intrusion. The Delta comprises six distinct agro-ecological zones with different potentials for rice-based farming systems (Nguyen, D. C. et al. 2007; Biggs 2015; Biggs et al. 2009; Fig. 17.1):

- The Alluvial Floodplain is the freshwater zone along the Mekong and Bassac (Hau Giang) Rivers, accounting for about 900,000 ha. The rivers and canals are tide-affected in the middle reaches of the floodplain, enabling farmers to irrigate and drain their land with the tides. This zone has fertile alluvial soils, and farmers practise intensive rice farming with two or three crops per year, while many have diversified into orchards, vegetables, and rice-fish aquaculture.

- Away from the main rivers, there are four large depressions. The Plain of Reeds in the north, accounting for about 500,000 ha, is the lowest part of the Delta at 0.5 metres below mean sea level. This zone floods in the wet season and features acid sulphate soils. Farmers traditionally planted deep-water rice in this zone but flood-control measures now permit intensive rice cultivation and rice combined with freshwater aquaculture.

- Similarly, the Long Xuyen Quadrangle, accounting for 400,000 ha, is subject to wet-season flooding and has acid sulphate soils. It was also a traditional area for deep-water rice, but since 2000 , investment in flood control and irrigation has enabled more intensive rice production as well as rice-fish aquaculture.

- The Trans-Bassac Depression lies to the west of the Bassac River and accounts for about 600,000 ha. This zone also has acid sulphate soils but is not seriously affected by flooding or saline intrusion, providing good conditions for intensive rice production and other field crops.

- The Ca Mau Peninsula encompasses about 800,000 ha at the southernmost part of the Delta where the Delta is actively growing due to sediment deposition. This zone is subject to dry-season saltwater 
intrusion, limiting rice production to a single wet-season crop. Large parts of this zone have been developed for shrimp farming.

- The Coastal Complex includes about 600,000 ha of coastal flats and sand ridges, much of which is subject to saline intrusion, though coastal dykes have altered the hydrology. Along with the Ca Mau Peninsula, this has been the major zone for the expansion of brackishwater shrimp farming.

About 17.5 million people live in the Delta, including Kinh (90\%), Khmer (6\%), Hoa (2\%), and Cham (2\%) ethnic groups, accounting for one-fifth of Vietnam's population. However, the population growth rate is only $0.3-0.5 \%$ due to out-migration (CGIAR 2016). Rice forms the basis of livelihoods for the millions of smallholders in the Delta, both as their staple food and as a major source of income. In 2016, Vietnam as a whole had 3.8 million ha of paddy land, producing over 40 million tons of unhusked rice, half of which came from the Delta. In the same year, Vietnam exported 4.5 million tons of milled rice worth USD 2 billion, $90 \%$ of which was produced in the Delta (Demont and Rutsaert 2017; Thang 2017). The planted area and yield of rice have increased over the past 20-30 years as irrigation and flood control have increased and as farmers have adopted high-yielding varieties (HYVs), increased fertiliser use, and small-scale mechanisation. In many parts of the Delta, farmers now cultivate three crops of rice per year.

However, the rice sector faces problems of low farm incomes and increased environmental hazards. Diversification of the farming system is now seen by both farmers and the government as a way to address these challenges. In 2000, the government issued the first of a series of policies to encourage farmers to diversify their production. Farmers responded by planting more non-rice crops on paddy land in the dry season, such as maize, vegetables, and watermelons, as well as combining rice with aquaculture. Fruit trees were also extensively planted on flood-protected upland areas (Nguyen, D. C. et al. 2007). In this chapter, we review the intensification and growth of rice production and assess the development of these more diversified rice-based farming systems.

\section{Profile of Rural Households}

A household survey conducted in the mid-2000s gives a snapshot of rural livelihoods in the different agro-ecological zones of the Delta (Nguyen, D. C. et al. 2007). Some key characteristics of the average household in 
Table 17.1 Characteristics of households in the Mekong Delta by agroecological zone, 2005

\begin{tabular}{|c|c|c|c|c|c|c|}
\hline \multirow[t]{2}{*}{ Variable } & \multicolumn{6}{|c|}{ Agro-ecological zone } \\
\hline & $\begin{array}{l}\text { Alluvial } \\
\text { Floodplain }\end{array}$ & $\begin{array}{l}\text { Plain of } \\
\text { Reeds }\end{array}$ & $\begin{array}{l}\text { Long } \\
\text { Xuyen Q. }\end{array}$ & $\begin{array}{l}\text { Trans- } \\
\text { Bassac D. }\end{array}$ & $\begin{array}{l}\text { Coastal } \\
\text { Complex }\end{array}$ & $\begin{array}{l}\text { Ca Mau } \\
\text { Peninsula }\end{array}$ \\
\hline Mean area owned (ha) & 1.36 & 1.83 & 1.40 & 1.75 & 2.51 & 2.08 \\
\hline Mean no. in household & 4.93 & 4.24 & 5.76 & 5.47 & 5.01 & 5.00 \\
\hline Mean no. aged 16-55 & 3.11 & 2.33 & 3.79 & 3.95 & 3.43 & 3.41 \\
\hline $\begin{array}{l}\text { Mean no. in off-farm } \\
\text { work }\end{array}$ & 0.64 & 0.05 & 0.42 & 0.28 & 0.29 & 0.34 \\
\hline $\begin{array}{l}\text { Mean no. in non-farm } \\
\text { work }\end{array}$ & 1.88 & 1.05 & 2.71 & 2.50 & 2.05 & 2.12 \\
\hline $\begin{array}{l}\text { Edcn. of head ( } \% \\
\text { scndry.) }\end{array}$ & 34 & 37 & 21 & 58 & 43 & 64 \\
\hline Gender of head $(\% \mathrm{~F})$ & 16.2 & 2.4 & 5.3 & 0.0 & 6.3 & 4.9 \\
\hline$\%$ owning pump & 74.7 & 76.2 & 78.9 & 50.0 & 91.4 & 27.4 \\
\hline$\%$ owning boat & 38.0 & 76.2 & 78.9 & 50.0 & 91.4 & 27.4 \\
\hline$\%$ owning sprayer & 73.6 & 57.2 & 68.4 & 63.3 & 2.9 & 0.0 \\
\hline$\%$ receiving loan & 44.2 & 42.9 & 71.1 & 71.7 & 85.5 & 90.2 \\
\hline
\end{tabular}

Source: Nguyen, D. C. et al. (2007)

each zone are presented in Table 17.1. The average farm size was uniformly small, but lowest in the more productive Alluvial Floodplain (1.4 ha) and largest in the Coastal Complex (2.5 ha). Household size averaged around five members throughout the Delta, with an average of two to four members of working age. The proportion of working-age members engaged in off-farm labouring was highest in the Alluvial Floodplain (20\%) but mostly below $10 \%$ in other regions. However, the proportion engaged in non-farm work was high across the Delta, ranging from $45 \%$ in the Plain of Reeds to over $70 \%$ in the Long Xuyen Quadrangle. The education level of the household head was similar across zones, with one to two-thirds having completed lower secondary school. Almost all household heads were men, but in the Alluvial Floodplain 16\% of households were headed by a woman. The ownership of key equipment varied across the zones depending on variations in livelihoods. Pumps were an essential item for most households (75-90\%) except in the Ca Mau Peninsula where there was less reliance on irrigation. Similarly, ownership of a boat was essential in the flood zones of the deep depressions and the Coastal Complex. Sprayers were owned by $60-70 \%$ of households 
in the major rice-growing areas but were less common in the coastal shrimp zones. The use of credit varied from around $40 \%$ in the Alluvial Floodplain to $90 \%$ in the Ca Mau Peninsula.

The different patterns of household land use are indicated in Fig. 17.3. Paddy land dominated in the Alluvial Floodplain and surrounding depressions, averaging between 1.0 and 1.5 ha. Orchards of $0.2-0.3$ ha were also a significant feature of land use in these zones. However, shrimp and fish farms were the dominant land use in the Coastal Complex and the Ca Mau Peninsula, averaging 2.0-2.4 ha.

The land-use patterns were partly reflected in the sources and levels of income (Table 17.2). Farmers in the Alluvial Floodplain and the adjacent depressions (Plain of Reeds and Long Xuyen Quadrangle) obtained $80-90 \%$ of their farm income from rice and field crops, earning USD 1300-1500 in 2005. In contrast, farmers in the Coastal Complex earned 85-90\% of farm income from shrimp and fish, with coastal farmers averaging USD 1700 from this source. Non-farm income was more significant for households in the Alluvial Floodplain, indicating greater livelihood diversification in this more accessible and densely populated zone. Overall, these farmers and those in the Coastal Complex obtained the highest incomes per household (USD 2100-2300) and per capita (USD 420470). Those in the Ca Mau Peninsula were the poorest, with about half the mean income of the more prosperous zones.

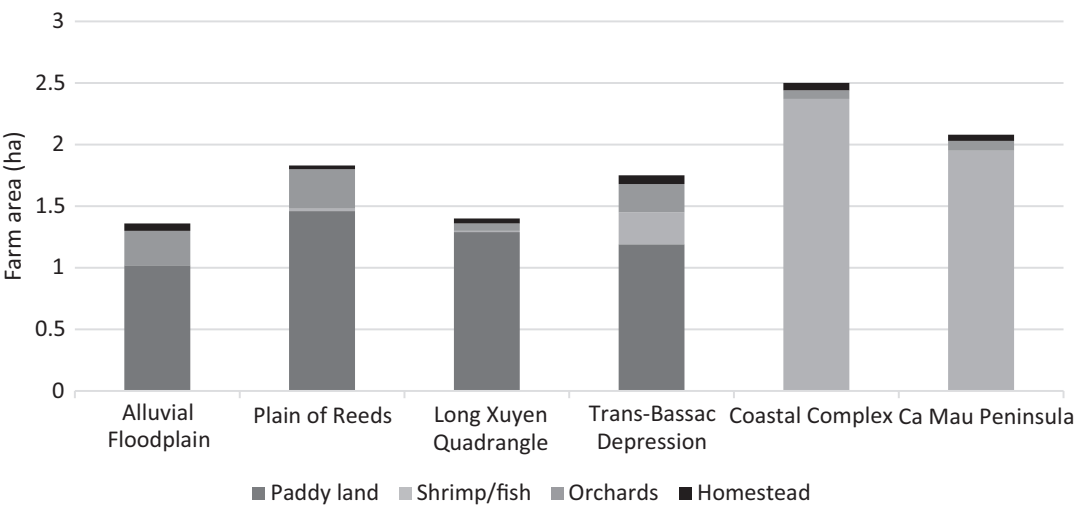

Fig. 17.3 Average farm area in Mekong Delta by land use and agro-ecological zone, 2005. (Source: Derived from data in Nguyen, D. C. et al. (2007)) 
Table 17.2 Mean household income by source and agro-ecological zone, 2005 (USD/year)

\begin{tabular}{lrllrrr}
\hline Source of income & \multicolumn{7}{l}{ Agro-ecological zone } & & & \\
\cline { 2 - 7 } & $\begin{array}{l}\text { Alluvial } \\
\text { Floodplain }\end{array}$ & $\begin{array}{l}\text { Plain of } \\
\text { Reeds }\end{array}$ & $\begin{array}{l}\text { Long } \\
\text { Xuyen }\end{array}$ & $\begin{array}{l}\text { Trans- } \\
\text { Bassac D. }\end{array}$ & $\begin{array}{l}\text { Coastal } \\
\text { Complex }\end{array}$ & $\begin{array}{c}\text { Ca Man } \\
\text { Peninsula }\end{array}$ \\
\hline Agriculture & 1652 & 1592 & 1482 & 1052 & 1932 & 937 \\
$\quad$ Rice-based & 1321 & 1470 & 1318 & 731 & 0 & 0 \\
farming & & & & & & \\
Fish/shrimp & 0 & 0 & 0 & 0 & 1598 & 673 \\
farming & 22 & 16 & 44 & 90 & 69 & 163 \\
Capture fisheries & 281 & 59 & 54 & 209 & 50 & 13 \\
Livestock & 28 & 47 & 67 & 22 & 216 & 89 \\
Off-farm work & 548 & 0 & 198 & 241 & 144 & 234 \\
Non-farm income & 96 & 0 & 56 & 258 & 48 & 0 \\
$\quad$ Remittances & 2296 & 1592 & 1736 & 1551 & 2124 & 1171 \\
All sources & 466 & 375 & 301 & 283 & 424 & 234 \\
Income per capita & & & & & & \\
\hline
\end{tabular}

Source: Nguyen, D. C. et al. (2007)

\section{The Intensification of Rice Farming}

Khmer farmers cultivated rice in the Delta for perhaps 2000 years (Chap. 1). From the eighteenth century, Vietnamese farmers occupied the Delta under the expanding Nguyen dynasty and began to extend the paddy area (Xuan and Matsui 1998; Le Coq et al. 2001). Traditionally, farmers settled along the river levees and along sand ridges in the coastal zone. The typical farm comprised a homestead (usually with livestock), ponds (used for aquaculture or as wild fish refuges and for domestic water use), dykes and gardens for trees and cash crops, and paddy fields for rice cultivation (sometimes combined with fish or shrimp culture) (Xuan and Matsui 1998). In some systems, farmers dug ditches, used as refuges for wild fish, and raised beds alongside for growing annual crops such as sugarcane (Nguyen, H. C. 1994).

During the eighteenth and nineteenth centuries, local rice varieties were cultivated in the wet season on the Alluvial Floodplain, while floating or deep-water rice was cultivated in the flooded zones such as the Plain of Reeds and the Long Xuyen Quadrangle (Le Coq et al. 2001; Biggs et al. 2009). ${ }^{1}$ After harvesting floating rice in December, farmers planted field crops such as mung bean, sweet potato, and maize, harvested in February 
or March (Xuan and Matsui 1998; Nguyen, H. C. 1994). Traditional, photosensitive varieties were cultivated in most areas of the Delta (Nguyen, H. C. 1994; Xuan and Matsui 1998). Early maturing varieties were cultivated in the Coastal Complex to permit harvesting before November when saline water intruded into the paddy fields. Medium-maturing varieties were grown in the tide-affected Alluvial Floodplain where water levels were difficult to control. Late-maturing varieties were cultivated in low-lying areas at risk of flooding. Floating or deep-water rice was mostly cultivated in the depressed zones where flooding in the wet season was inevitable - the Plain of Reeds and the Long Xuyen Quadrangle (Nguyen, H. C., 1994; Nguyen and Howie 2018).

The development of the Delta for rice-based farming systems can be divided into three stages: (1) adapting to existing conditions, (2) semicontrol, and (3) total control (Le Coq et al. 2001; Kakonen 2008; Biggs et al. 2009; Vormoor 2010). For the first 200 years of settlement by Kinh farmers, there was little or no infrastructure for rice farming, other than the canals that farmers progressively constructed. Farmers cultivated only one rice crop per year where conditions were suitable, whether traditional wet-season rice or floating rice. They also harvested wild fish in the paddy fields during the wet season and planted dry-season vegetable crops (Vo 1975; Nguyen, H. C. 1993).

In the second stage, from the mid-1970s, irrigation infrastructure was developed, permitting the intensification of rice production using modern varieties (Le Coq et al. 2001; Kakonen 2008; Biggs et al. 2009). A single crop of local rice continued to be cultivated under rainfed conditions on higher land, while single- or double-cropping of modern varieties was introduced across the Delta where low dykes and irrigation infrastructure had been constructed. Many farmers accessed irrigation water using locally developed, portable, axial-flow (or “shrimp-tail”) pumps (Nguyen, V. K. et al. 2016; Biggs et al. 2009).

In the third stage, following a 1996 government decision, increased investment in raising dykes and extending internal irrigation canals enabled widespread triple-cropping of rice (Yasuyuki 2001; Biggs et al. 2009; Nguyen, V. K. et al. 2016). ${ }^{2}$ For example, farmers in Cai Lay District of Tien Giang Province began triple-cropping in the late 1990s (Berg et al. 2017). An Giang and Dong Thap Provinces also started to raise dykes to enable triple-cropping, with the greatest progress after 2000 (Nguyen et al. 2016). The central government offered direct financial support to provinces, districts, and communes to build dykes to increase the extent of 
triple-cropping even in provinces subject to wet-season flooding. The area of irrigated land increased from 52\% of the Delta in 1990 to $91 \%$ in 2002 (CGIAR 2016). ${ }^{3}$

With the expansion of irrigation and increased cropping intensity, the area of rice planted in the Delta increased from 3.2 million ha in 1995 to 4.3 million ha in 2016, an annual increase of 1.4\% (Fig. 17.4). Most of this increase came from the main wet-season (autumn) crop, the share of which increased from $44 \%$ to $55 \%$. Farmers tended to replace the dryseason winter crop with an HYV crop in spring. The winter crop fell to $8 \%$ of the total area while the spring crop increased from $32 \%$ to $36 \%$, with the main increase occurring in the period 1995-2000. Farmers shifted from winter rice to other dry-season crops such as maize, sweet potatoes, cassava, and vegetables, or left the land idle in this season. In coastal areas, farmers shifted to brackish-water shrimp farming in the dry season.

The total production of paddy rice has doubled from 12.8 million tons in 1995 to 24.2 million tons in 2016, an annual increase of $3.2 \%$ (Fig. 17.5). The increase in production was about equally due to the increase in planted area and an increase in yields. The yield of the main autumn crop increased from $3.8 \mathrm{t} /$ ha to $5.3 \mathrm{t} / \mathrm{ha}$, that of the spring crop from $5.2 \mathrm{t} / \mathrm{h}$ a to close to $7.0 \mathrm{t} / \mathrm{ha}$, and that of the winter crop from $2.9 \mathrm{t} / \mathrm{ha}$ to $4.3 \mathrm{t} / \mathrm{ha}$ (Fig. 17.5). The yield increase in all seasons was attributable to better water management, use of HYVs, and greater use of fertilisers.

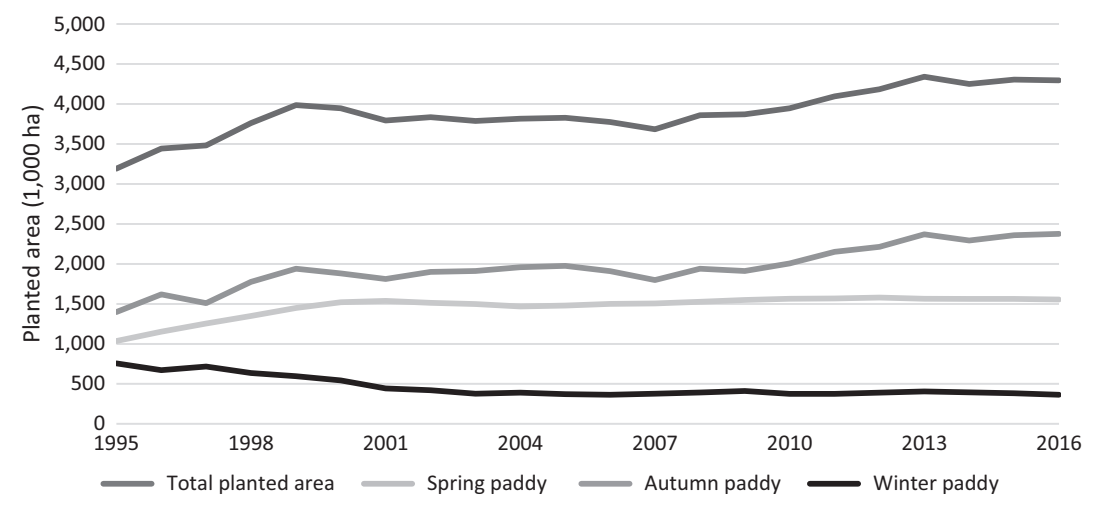

Fig. 17.4 Planted area of rice in the Mekong Delta by season, 1995-2016. (Source: General Statistics Office 2016) 
Despite this growth in area, yields, and production in the Delta, the rice sector faces several challenges (Nguyen, D. C. 2011). The focus has been on producing high-yield but low-quality rice, especially for the export market, with consequent low farm-gate prices (Demont and Rutsaert 2017). The use of inputs has increased, resulting in increased yields, but the net returns to rice farmers remain low (Berg et al. 2017). The use of fertiliser increased from $40 \mathrm{~kg}$ per ha in 1976-1981 to $120 \mathrm{~kg} / \mathrm{ha}$ in 1987-1988 (Xuan and Matsui 1998) and reached over $600 \mathrm{~kg}$ per ha in 2015 (Nguyen et al. 2018). The application of pesticides increased three to six times from 2000 to 2015 . The cost of these inputs has also increased, adding to the cost-price squeeze farmers are facing.

Rice production in the Delta also faces a series of interconnected environmental problems. The intensification of rice cultivation in the last 15 years has led to an increase in soil and water pollution from the overuse of agricultural chemicals (Nguyen, D. C. et al. 2015; Berg et al. 2017), and reduction in wild fish supply (Nguyen et al. 2018). Moreover, the Mekong Delta is highly vulnerable to the effects of climate change, including sealevel rise, increased flooding, and saline intrusion, particularly in the Coastal Complex and the Ca Mau Peninsula (Dasgupta et al. 2007; Phạm
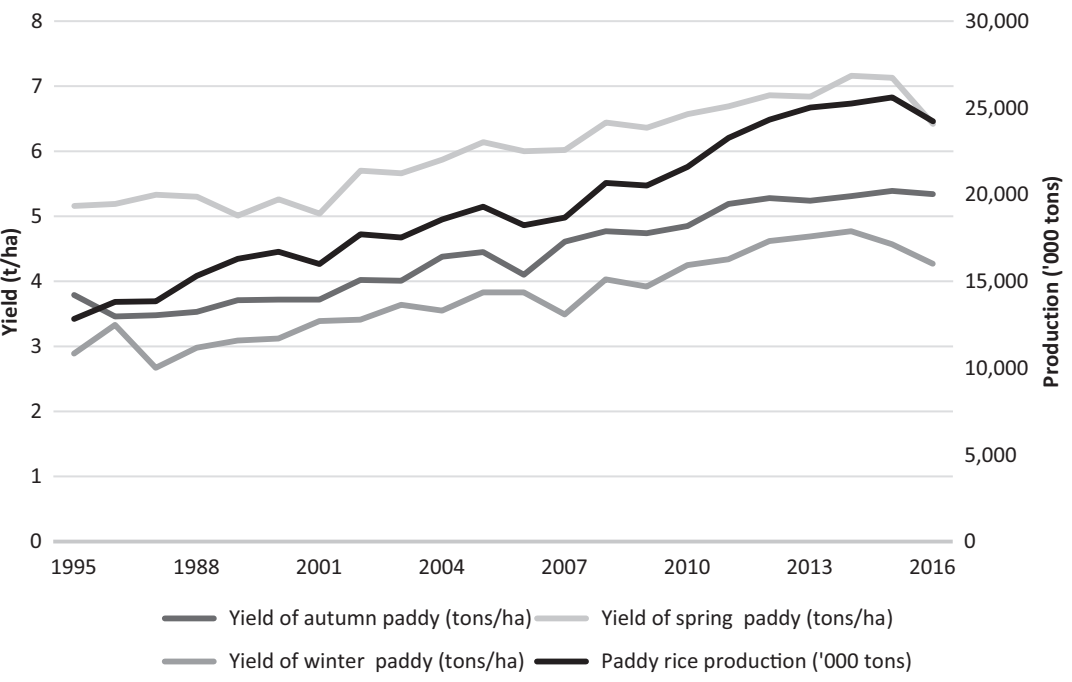

Fig. 17.5 Paddy yields by season and total paddy production in the Mekong Delta, 1995-2016. (Source: General Statistics Office 2016) 
and Furukawa 2007; MONRE 2009). Recent evidence shows that saline intrusion is having adverse impacts on both rice and rice-shrimp farming systems (Mainuddin et al. 2011, 2013; Ling et al. 2015; Thuy and Anh 2015; USAID 2016; Leigh et al. 2017; Stewart-Koster et al. 2017).

\section{Diversification of Rice-Based Farming Systems}

Farmers in the Delta have always combined other livelihood activities with rice production, giving rise to a range of rice-based farming systems in the different agro-ecological zones. With the trends in rice production described above and official encouragement to diversify production, a range of farming systems have been developed since the 1990s (Bosma et al. 2005; Tong 2017). The Delta now has seven dominant rice-based farming systems (Xuan and Matsui 1998):

- rice-rice-rice

- rice-rice

- rice-upland crops

- rice-livestock

- rice-wild fish

- rice-freshwater aquaculture

- rice-saline aquaculture

In addition, there has been a widespread conversion of paddy land to orchards in the Alluvial Floodplain. Trends in farming systems over the past 40 years are summarised in Table 17.3.

As described in the previous section, double- and triple-cropping of rice have expanded mostly in the Alluvial Floodplain and in the adjacent broad depressions. Systems alternating rice and upland crops have expanded on the natural levees and back swamps of the upper floodplain and on coastal sand ridges. Rice-livestock farming systems, in which the paddy fields are used for rice while ducks, chickens, pigs, cattle, or buffaloes are raised in the home yard, are found in most zones of the Delta (Xuan and Matsui 1998). The rice-wild fish farming systems are found in the Ca Mau Peninsula and in the Long Xuyen Quadrangle and Plain of Reeds. Farmers cultivate only one local rice crop from May to December and harvest wild fish from paddy fields and canals during the cropping season. The ricefreshwater aquaculture (fish and freshwater prawn) systems have mostly expanded in Tien Giang and Can Tho Provinces in the tide-affected 


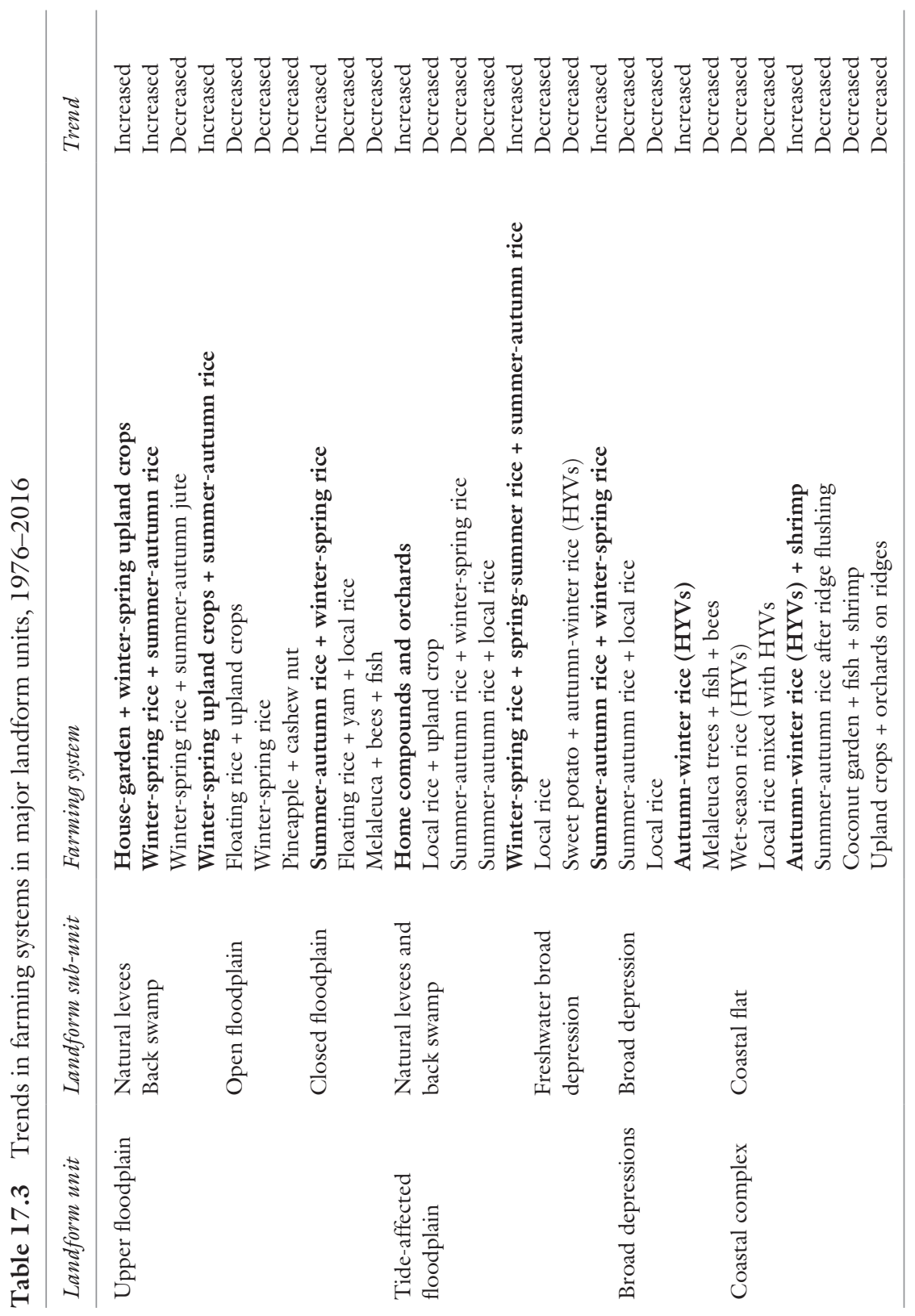


Alluvial Floodplain (Berg et al. 2017; Håkan 2002; Xuan and Matsui 1998). From 2000, with greater flood control, the rice-freshwater shrimp system was extended into the deep flood areas of An Giang and Dong Thap Provinces (the Long Xuyen Quadrangle and the Plain of Reeds) (Nguyen, V. K. 2014). Rice-brackish water shrimp farming systems have evolved over 80 years and are found in the coastal provinces of the Delta (Xuan and Matsui 1998; USAID 2016). Farmers cultivate one local rice crop in the wet season, when rainfall and freshwater flows enable salinity to be flushed out of the paddy fields, and modify the fields to culture brackish-water shrimp in the dry season. The main rice-based systems are discussed in more detail below.

\section{Rice and Upland Crops}

As described above, farmers traditionally planted field crops in upland plots in or near the homestead. In recent years, farmers have begun to allocate paddy land to these crops in some seasons, thereby increasing and diversifying their incomes. This trend has recently received encouragement from the government, which was previously intent on retaining all paddy land in the Delta for rice production. The Ministry of Agriculture and Rural Development (MARD) announced a land-use plan for 20142020 that mandates more flexible use of paddy land (Table 17.4). The plan encourages provinces to shift from rice to maize, soybean, sesame, vegetables, flowers, animal feed, and aquaculture. In total, the plan envisages a reduction of 316,000 ha of rice ( $7 \%$ of the 2013 rice area), mainly in the dry season, and an equivalent increase in non-rice crops, over half of which is to be taken up by maize $(83,000 \mathrm{ha})$ and vegetable and flower crops $(87,000 \mathrm{ha})$. More importantly, the government issued a resolution in 2017 to develop strategies for sustainable and climate-resilient development in the Delta. ${ }^{4}$ This resolution provided the basis for reducing the extent of triple-cropping of rice and further diversifying cropping systems.

Farmers have developed appropriate rice-based cropping systems depending on local hydrological, soil, and topographical conditions. Two common patterns that have emerged are (1) one crop of rice followed by one crop of maize or sweet potatoes or several crops of vegetables and (2) two crops of rice followed by one crop of maize or sweet potatoes or one crop of vegetables. From 1995 to 2016, the area of maize has increased from just over 20,000 ha to nearly 35,000 ha, and the area of sweet potatoes has doubled from about 10,000 ha to 20,000 ha (General Statistics 
Table 17.4 MARD land-use plan for paddy land in Mekong Delta for 20142020 period

\begin{tabular}{|c|c|c|c|c|c|c|}
\hline \multirow[t]{2}{*}{ Crop } & \multirow{2}{*}{$\begin{array}{l}\text { Area in } \\
2013(\text { ha } \times \\
\left.10^{3}\right)\end{array}$} & \multicolumn{4}{|c|}{$\begin{array}{l}\text { Planned change in land allocation, } \\
2014-2020\left(\text { ha } \times 10^{3}\right)\end{array}$} & \multirow{2}{*}{$\begin{array}{l}\text { Area in } \\
2020(\text { ha } \times \\
\left.10^{3}\right)\end{array}$} \\
\hline & & Spring & Autumn & Winter & Total & \\
\hline Rice & 4338 & $(160)$ & (129) & $(28)$ & $(316)$ & 4022 \\
\hline Maize & 40 & 29 & 52 & 1 & 83 & 123 \\
\hline Soybean & 2 & 17 & 4 & 0 & 21 & 23 \\
\hline Sesame & 29 & 14 & 11 & 0 & 25 & 54 \\
\hline $\begin{array}{l}\text { Vegetables and } \\
\text { flowers }\end{array}$ & 254 & 50 & 34 & 3 & 87 & 341 \\
\hline Animal feed & 7 & 17 & 4 & 3 & 24 & 31 \\
\hline $\begin{array}{l}\text { Rice and } \\
\text { aquaculture }\end{array}$ & 174 & 5 & 8 & 42 & 54 & 228 \\
\hline Other & 53 & 13 & 9 & 0 & 22 & 75 \\
\hline
\end{tabular}

Source: Approved land-use plan for changing cropping systems on rice land in the 2014-2020 period, MARD 31 July 2014

Office 2016). The area of all types of vegetables increased sharply from under 20,000 ha in 2000 to over 45,000 ha in 2011 .

\section{Rice and Livestock}

Pigs are an integral part of farming systems in the Delta. Small-scale pig raising is very common-about $70 \%$ of smallholders own a pigpen, raising several pigs-while some operations raise several thousand head (Huynh et al. 2007). This activity creates employment for household members and provides a major source of income (Huynh et al. 2007). Farmers face market and disease risks, causing the number of pigs to fluctuate as prices vary and outbreaks of diseases such as foot-and-mouth disease or swine influenza occur. Nevertheless, total numbers in the Delta increased from 2.4 million in 1995 to 3.8 million in 2016.

Farmers traditionally raised chickens and ducks inside the homestead for both meat and eggs (Xuan and Matsui 1998). They were fed with rice, food waste, and local aquatic animals such as fish and snails. Each household raised small numbers of chickens and ducks for home consumption, or up to several hundred for sale. Some specialised, largescale farmers raised up to several thousand head. However, the bird flu epidemic in the mid-2000s $s^{5}$ had a negative impact, with many small-scale 
farmers ceasing to raise poultry. The number of poultry in the Delta dropped sharply from 51.5 million in 2003 to 31.4 million in 2005 . Nevertheless, medium- and large-scale poultry farming has increased dramatically since 2005, with total numbers reaching 64.7 million in 2016 (General Statistics Office 2016).

Before the 1980s, cattle and buffaloes were used for draught power, both ploughing and transportation (Xuan and Matsui 1998). However, following the doi moi reforms, most farmers have replaced buffaloes with two-wheeled tractors imported from Japan and China. Consequently, the number of buffaloes in the Delta has declined dramatically, from 113,000 in 1995 to 40,000 in 2001, with slower decline thereafter to 31,000 in 2016 (General Statistics Office 2016). In contrast, the number of cattle increased sharply, from 150,000 in 1995 to 680,000 in 2006 , and continues to hover around 700,000. The primary use of cattle is now for commercial beef production, with high demand in nearby Ho Chi Minh City. Ricegrowing households fatten up to ten cattle in sheds in the house compound (Fig. 17.6). Farmers grow forage grasses or use rice straw as forage, and also buy imported soybean cake.

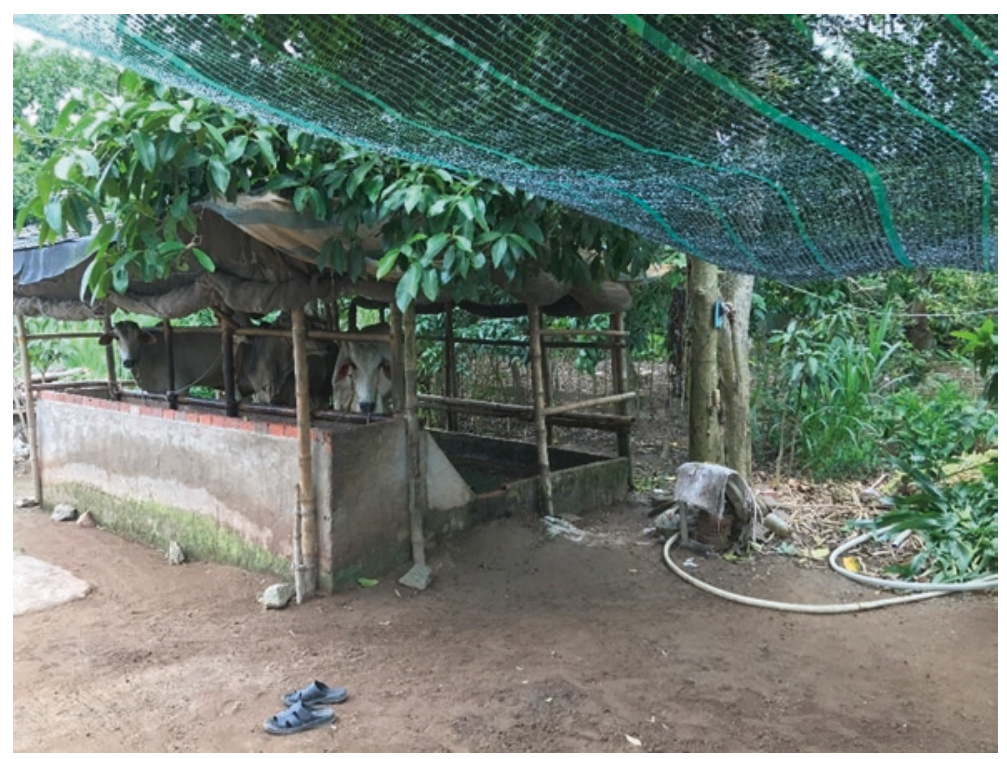

Fig. 17.6 Cattle being fattened for sale in a farmyard shed in My An Commune, Cho Moi District, An Giang Province. (Source: Nguyen Van Kien, September 2017) 


\section{Rice and Aquaculture}

Four main rice-based farming systems in the Mekong Delta incorporate the capture and/or rearing of aquatic species (Xuan and Matsui 1998):

- rice-wild fish capture

- rice-aquaculture (freshwater fish, e.g., Pangasius spp.)

- rice-aquaculture (freshwater shrimp, e.g., Macrobrachium rosenbergii)

- rice-aquaculture (brackish-water shrimp, e.g., Penaeus monodon)

Wild fish capture has long been practised in the transplanted rice zones of the Delta, producing about 190,000 tons/year. Farmers dug ponds or ditches in the paddy fields to create refuges for fish during the rice-growing season. After the rice harvest, fish moved to the ponds where farmers could harvest them for home consumption. This system could yield 2-3 tons of rice/ha and 150-200 kg of fish/ha (Xuan and Matsui 1998). The average yearly consumption of fresh fish products was estimated at $21 \mathrm{~kg}$ per capita in 1995 (Rothuis 1998). Harvesting wild fish for sale provided additional income for most households. This system dominated before the rapid spread of HYV rice in the Delta (Xuan and Matsui 1998), significantly reducing wild fish capture. For example, the total fish catch in the upper delta decreased by one-third from 1995 to 2016.

While traditional wild fish capture has declined, fish aquaculture has markedly increased (Fig. 17.7). This involves rearing fish in pens or floating cages and, increasingly, in ponds along the main rivers and canals using pelleted feed. Local catfish (Pangasius spp.) are the main species reared. The catfish industry began in the late 1990s in An Giang and Dong Thap Provinces in the upper Delta, and within a decade involved 800,000 farmers managing 6000 ha of ponds to produce 1.5 million tons, much of it exported to the US and European Union (EU). In the last decade there have been trade disputes with the US and concerns over quality in the EU, causing fluctuations in demand. Nevertheless, the area of freshwater fish aquaculture has continued to increase. For example, in An Giang Province, the area has increased from 1465 ha in 1995 to 1690 ha in 2016 (Fig. 17.8).

Systems combining rice with freshwater shrimp are mainly found in low-lying areas of the Delta. In the 1990s, farmers in Phung Hiep District, Hau Giang Province, in the Trans-Bassac Depression, began doublecropping with short-medium duration HYVs integrated with giant fresh- 


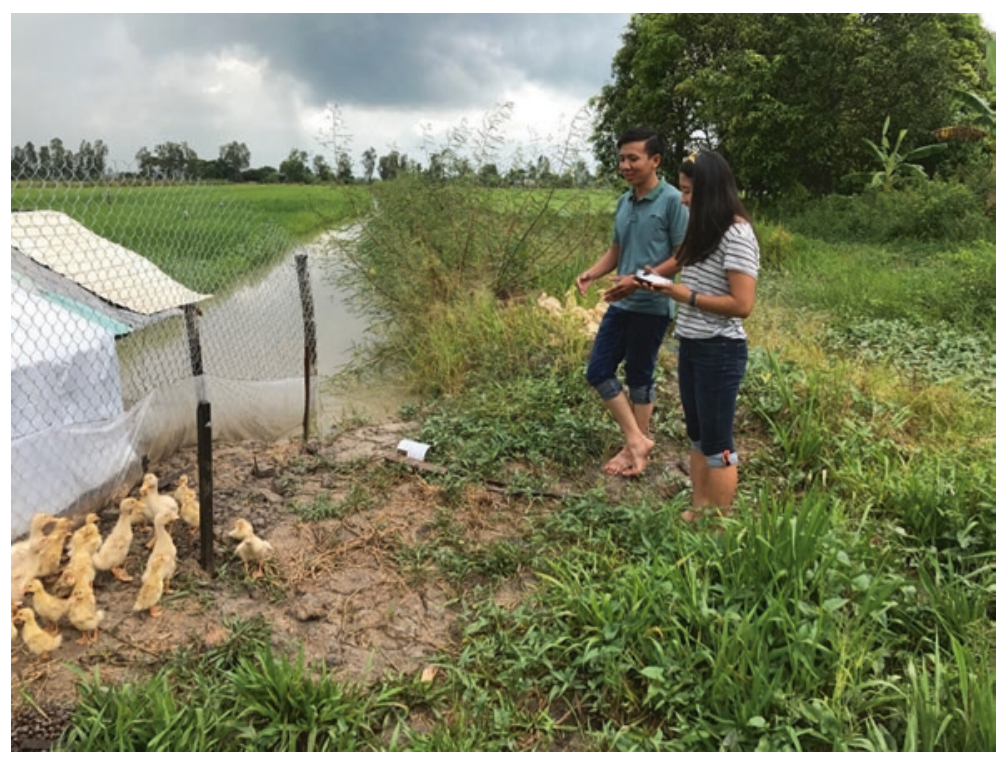

Fig. 17.7 Rice-fish-poultry system in My Phu Dong Commune, Thoai Son District, An Giang Province. (Source: Nguyen Van Kien, September 2017)

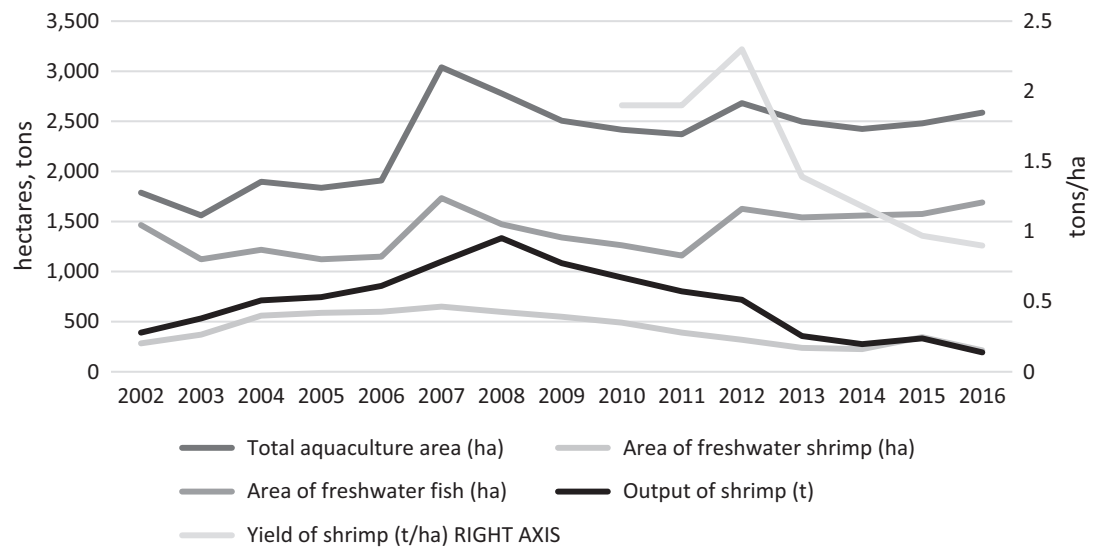

Fig. 17.8 Area, yield, and production of freshwater shrimp and fish in An Giang Province. (Source: Statistical Office of An Giang Province (2016)) 
water shrimp or fish such as snakehead and climbing perch (Xuan and Matsui 1998). The rice-shrimp farming system was introduced to An Giang Province in the Long Xuyen Quadrangle during the flood season of 2000. Tu Xang in Phu Thuan Commune of Thoai Son District cultured several hectares of shrimp and obtained a high economic return, thanks to good yields and a high price. ${ }^{6}$ In 2002, farmers in Chau Phu District followed this practice and cultured shrimp over 282 ha in the flood season, rotated with HYV rice in the dry season (Fig. 17.9). Nguyen (2014)

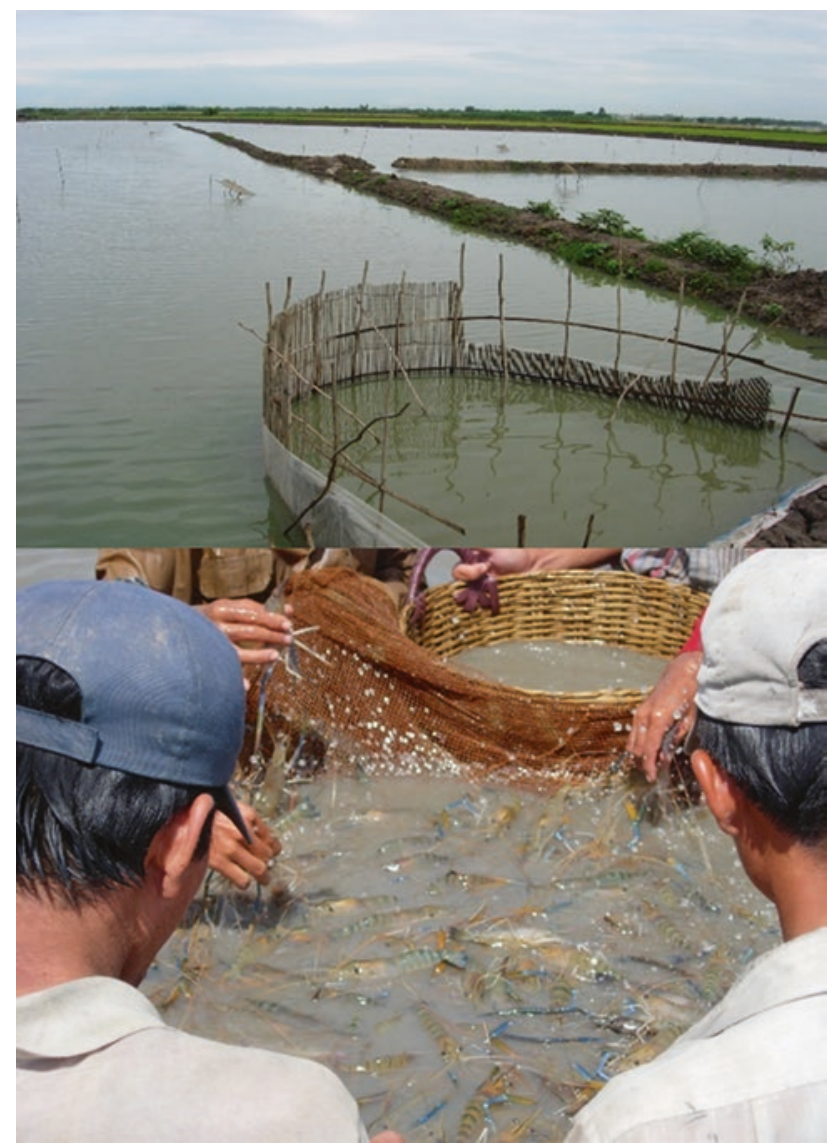

Fig. 17.9 Freshwater shrimp farming in Vinh Thanh Trung Commune, Chau Phu District, An Giang Province. (Source: Nguyen Van Kien) 
Table 17.5 Economic returns to rice-freshwater shrimp farming in An Giang, 2006

\begin{tabular}{lllrr}
\hline Parameter & Units & Rice & Shrimp & \multicolumn{1}{c}{ Total } \\
\hline Yield & Tons $/ \mathrm{ha}$ & 6.76 & & \\
Price on sale & VND $/ \mathrm{kg} \times 10^{3}$ & 2.269 & & \\
Total benefit & VND $/ \mathrm{ha} \times 10^{3}$ & 15,338 & 102,540 & 117,878 \\
Total cost & VND $/ \mathrm{ha} \times 10^{3}$ & 7437 & 57,790 & 65,117 \\
Net benefit & VND $/$ ha $\times 10^{3}$ & 7901 & 44,750 & 52,761 \\
Net benefit & USD $/$ ha & 339 & 1920 & 2263 \\
\hline
\end{tabular}

Source: Nguyen, V. K. (2014)

Note: USD 1 = VND 23,000

found that the net return from one rice-shrimp cycle in 2006 was USD $2263,85 \%$ of which was from the shrimp activity. This was much higher than the net return from double- and triple-cropping rice in An Giang (Table 17.5). Consequently, the provincial government formulated a policy to promote "flood-based livelihoods" through rice-shrimp systems (An Giang People's Committee 2006). Farmers in Dong Thap Province in the Plain of Reeds followed those in An Giang, beginning shrimp culture in the flood season of 2004. In 2006 there were 146 ha of ponds, producing 230 tons. This increased to 700 ha producing 1200 tons in 2010 .

The area and output of freshwater shrimp increased markedly up to about 2008. However, production has declined significantly in the past decade due to chemical pollution from neighbouring HYV rice paddies, reduction in flood levels (the flood peak in 2015 was the lowest in 100 years), and unstable market prices. The area of shrimp ponds in An Giang peaked at 650 ha in 2007 and fell to 214 ha by 2016, while the average yield fell sharply from over 2 tons/ha in 2012 to be less than 1 ton/ha in 2016 (Fig. 17.8 above). With this decline in area and yield, total production in An Giang fell from 1334 tons in 2008 to just 194 tons in 2016. The same trends have occurred in both An Giang and Dong Thap Provinces. ${ }^{7}$

Rice combined with brackish-water shrimp was observed in five coastal provinces as early as the 1930s (Nguyen, H. C. 1994). In 1984, there was about 5000 ha of rice-shrimp farming (Xuan and Matsui 1998). At this time, the yield of shrimp averaged $640 \mathrm{~kg} / \mathrm{ha}$ and the yield of rice ranged from 3.5 to 4.0 tons/ha (Xuan and Matsui 1998). In 2000, the total area of rice-shrimp was 71,000 ha, distributed across five coastal provinces: Ben Tre, Soc Trang, Bac Lieu, Ca Mau, and Kien Giang. This had increased 
to 153,000 ha in 2014 (USAID 2016). These semi-intensive rice-shrimp systems include one crop of wet-season rice and one or two crops of tiger shrimp or white-leg shrimp (USAID 2016). This system is very common in Soc Trang, Ca Mau, Kien Giang, Ben Tre, and Tra Vinh Provinces. Total brackish-water shrimp production was 65,000 tons with yields ranging from 300 to $500 \mathrm{~kg} / \mathrm{ha}$ (USAID 2016). Preston and Clayton (2003) found that farmers' incomes had improved significantly from adopting this system.

The rice-shrimp systems have several technical problems that threaten their sustainability. Nutrient use in rice-shrimp systems is less efficient than in dedicated shrimp grow-out ponds, causing low shrimp survival rates and low production (Dien et al. 2018). Leigh et al. (2017) found water temperature and salinity were too high in the dry season and dissolved oxygen was too low, causing low survival rate and low shrimp production. The rice crop was also affected adversely by high salinity levels (Leigh et al. 2017). Although rice-shrimp systems are economically and environmentally viable, farmers have tended to switch to intensive shrimp production systems (Preston and Clayton 2003).

Climate change poses new risks to rice-shrimp farming systems. Early saline water intrusion in November negatively affects rice yields while contributing to an accumulation of soil salinity over time (Preston and Clayton 2003; ACIAR 2016). The impacts of climate change have increased in recent years. Saline intrusion due to drought events occurs more frequently. The historical drought event in 2015 caused severe damage to rice, vegetables, flowers, fruit trees, livestock, buffaloes, cattle, and small fishponds. The coastal provinces were most affected, with rice, fruit, and aquaculture taking the brunt of the impact.

\section{Conclusion}

Rice-based farming systems in the Mekong Delta have been transformed over the last three decades due to farmer initiatives and government policy. Facing an urgent need to boost rice production after 1975, the government increased investment in water control and irrigation and promoted the intensification of rice farming through green revolution technology, leading to widespread adoption of double- and triple-cropping systems. With the expansion of irrigation and increased cropping intensity, the area of rice in the Delta increased from around 2.0 million ha in the immediate post-war decade to 3.2 million ha in 1995 and 4.3 million ha 
in 2016. The yield of the main wet-season (autumn) crop increased from about $2 \mathrm{t} / \mathrm{ha}$ in 1975 to $3.8 \mathrm{t} / \mathrm{ha}$ in 1995 and $5.3 \mathrm{t} / \mathrm{ha}$ in 2016 due to better water management, use of HYVs, and greater use of fertilisers. Total production of paddy rice was only about 4 million tons in 1975, increasing threefold to 12.8 million tons in 1995 and doubling again to 24.2 million tons in 2016. The increase is attributable in equal measure to the increase in planted area and the increase in yields. From being a net importer of rice in the 1970s and 1980s, Vietnam exported 1.4 million tons in 1989 following the first phase of intensification and market reforms. In 2016, exports totalled 4.5 million tons worth USD 2 billion, 90\% of which was produced in the Delta. By any standard, this has been an amazing economic transformation.

However, the focus on rice intensification has shifted since 2000 as the impacts on farmer livelihoods and the environment have become apparent. Locking farmers into producing low-quality rice for the export market has not provided them with adequate returns, especially as both domestic and global demand have shifted in favour of higher-quality rice and more diverse diets. Specialisation in continuous rice production has also restricted the dietary diversity of rural households. Intensive use of fertilisers and pesticides has led to soil and water pollution and reduction in wild food supply. Moreover, the "total management" of hydrology in the Delta has had major impacts on water flows, sedimentation processes, aquatic species, and land-use options. The Delta is also highly vulnerable to the effects of climate change, including sea-level rise, increased drought and flooding, and saline intrusion, the latter affecting up to half the surface area.

In response, the government has progressively relaxed its restrictions on the use of paddy lands-originally conceived to achieve food security and maintain export earnings. Hence, rice-based farming systems have become more diversified in the last two decades, with the increased use of paddy lands for non-rice field crops, orchards, and freshwater and brackishwater aquaculture. Irrigated dry-season horticultural crops and productive and profitable orchards now abound in the Alluvial Floodplain. While the traditional inland fish catch has declined, the production of freshwater fish in ponds, especially local catfish, has developed into a major export industry in the upper Delta. Freshwater shrimp, however, after a rapid increase since 1990, appears to be in decline. In the Coastal Complex and the Ca Mau Peninsula, brackish-water shrimp culture has had a longer and more successful history, though it is facing challenges due to disease outbreaks, market fluctuations, and climate change. 
The most recent indication of the shift in policy was the November 2017 resolution in support of sustainable development strategies for the Delta. These strategies include (1) promotion of high-quality rice, (2) reduction in the area planted to rice, (3) further diversification of farming systems, and (4) promotion of agro-ecological and organic agriculture. Targets have been set to increase the quality rather than the volume of rice and to diversify rice-based farming systems to make the best use of each agro-ecological zone in the Delta. Even traditional floating rice is being encouraged in the remaining deep-flooding pockets. Reduction in the area planted with rice is intended to help counter the overuse of chemicals in the paddy field ecosystem while opening further opportunities for the diverse range of crop, livestock, and aquatic products that are increasingly in demand in Vietnam's cities. Promotion of integrated (or agroecological) rice-based farming systems is intended to provide the basis for more profitable and sustainable rural livelihoods in the Delta, with greater adaptability to changing markets and climate.

\section{Notes}

1. Floating rice can elongate at rates of $20-25 \mathrm{~cm} /$ day as the floodwaters rise (Cummings 1978).

2. Decision No. 99/TTg, 9 February 1996.

3. By 2015 , the area planted to floating rice had fallen to only 200 ha (Nguyen, V. K. and Pittock 2016). However, the floating rice system has been reevaluated in recent years (Nguyen, V. K. and Huynh 2015), leading to a plan to expand to 500 ha in deep-water areas by 2030 (An Giang Department of Agriculture and Rural Development 2014).

4. Resolution No. 120/NQ-CP of 17 November 2017.

5. Highly Pathogenic H5Nl Avian Influenza Viruses. The Clade 1 viruses first detected in late 2003 continued to circulate until 2007 (Wan et al. 2008).

6. Personal communication with Tu Xang in December 2016.

7. Personal communication with leader of Tam Nong Department of Agriculture and Rural Development, Dong Thap Province.

\section{REFERENCES}

ACIAR, 2016. Improving the Sustainability of Rice-Shrimp Farming Systems in the Mekong Delta, Vietnam. Canberra: Australian Centre for International Agriculture Research.

An Giang Department of Agriculture and Rural Development, 2014. Land use planning for rice cultivation using high technology in An Giang Province until 
2020 and vision for 2030. Long Xuyen: An Giang Department of Agriculture and Rural Development.

An Giang People's Committee, 2006. Chuong trinh khai thac loi the mua nuoc noi tinh An Giang giai doan 2002-2010 (Programs for exploitation of the benefits of the 'rising water season' of An Giang Province from 2002 to 2010). Long Xuyen: An Giang People's Committee.

Berg, H. K., Soderholm, A. E., Soderstrom, A.-S., and Tam, N. T., 2017. Recognizing wetland ecosystem services for sustainable rice farming in the Mekong Delta, Vietnam. Sustainability Science 12: 137-154.

Biggs, D., 2015. Promiscuous transmission and encapsulated knowledge: a material-semiotic approach to modern rice in the Mekong Delta. In F. Bray, P. A. Coclanis, E. L. Fields-Black, and D. Schäfer, eds. Rice: Global Networks and New Histories, chapter 5. Cambridge: Cambridge University Press.

Biggs, D., Miller, F., Chu, H. T., and Molle, F., 2009. The Delta machine: water management in the Vietnamese Mekong Delta in historical and contemporary perspectives. In F. Molle, T. Foran, and M. Karonen, eds., Contested Waterscapes in the Mekong Region: Hydropower, Livelihoods and Governance, pp. 203-225. London: Earthscan.

Bosma, R. H., Udo, H. M. J., Verreth, J. A. J., Visser, L. E., and Cao Quốc Nam, 2005. Agricultural diversification in the Mekong delta: farmers' motives and contributions to livelihoods. Asian Journal of Agriculture and Development 2: 49-66.

CGIAR, 2016. Assessment Report: Drought and Salinity Intrusion in the Mekong River Delta of Vietnam. CGIAR Research Centres in Southeast Asia, 25-28 April 2016.

Cummings, R., 1978. Agricultural change in Vietnam's floating rice region. Human Organization 37(3): 235-245.

Dasgupta, S., Benoit, L., Craig, M., David, W., and Yan, J., 2007. The Impact of Sea-Level Rise on Developing Countries: A Comparative Analysis. Washington, DC: World Bank.

Demont, M., and Rutsaert, P., 2017. Restructuring the Vietnamese rice sector: towards increasing sustainability. Sustainability 9: 325.

Dien, L. D., Hiep, L. H., Hao, N. V., Sammut, J., and Burford, M. A., 2018. Comparing nutrient budgets in integrated rice-shrimp ponds and shrimp growout ponds. Aquaculture 484: 250-258.

General Statistics Office, 2016. Agriculture, Forestry and Fisheries. Hanoi: General Statistics Office.

Håkan, B., 2002. Rice monoculture and integrated rice-fish farming in the Mekong Delta, Vietnam-economic and ecological considerations. Ecological Economics 41(1): 95-107.

Huynh, T. T. T., Aarnink, A. J. A., Drucker, A., and Verstegen, M. W. A., 2007. Pig production in Cambodia, Laos, Philippines, and Vietnam: a review. Asian Journal of Agriculture and Development 4(1): 69-90. 
Kakonen, M., 2008. Mekong Delta at the crossroads: more control or adaptation. Ambio 37(3): 205-212.

Le Coq, J. F., Dufumier, M., and Trebuil, G., 2001. History of Rice Production in the Mekong Delta. Paper presented at Third EUROSEAS Conference, London, 6-7 September 2001.

Leigh, C., Hiep, L. H., Stewart-Koster, B., Vien, D. M., Condon, J., Sang, N. V., et al., 2017. Concurrent rice-shrimp-crab farming systems in the Mekong Delta: are conditions (sub) optimal for crop production and survival? Aquaculture Research 48: 5251-5262.

Ling, F. H., Tamura, M., Yasuhara, K., Ajima, K., and Trinh, C. V., 2015. Reducing flood risks in rural households: a survey of perception and adaptation in the Mekong delta. Climate Change 132: 209-222.

Mainuddin, M., Kirby, M., and Hoanh, C. T., 2011. Adaptation to climate change for food security in the lower Mekong Basin. Food Security 3(4): 433-450.

Mainuddin, M., Kirby, M., and Hoanh, C. T., 2013. Impact of climate change on rainfed rice and options for adaptation in the lower Mekong Basin. Natural Hazards 66: 905-938.

MONRE, 2009. Climate Change and Sea-Level Rise Scenarios for Vietnam. Hanoi: Ministry of Natural Resources and Environment.

Nguyen Huu Chiem, 1993. Geo-pedological study of the Mekong Delta. Southeast Asian Studies 31(2): 158-186.

Nguyen Huu Chiem, 1994. Former and present cropping patterns in the Mekong Delta. Southeast Asian Studies 31(4): 345-384.

Nguyen, D. C., 2011. Transformation of Farming Systems in Coastal Mekong Delta: Seeking for Better Management and Sustainability. Paper presented at 6th International Symposium on Structural Transformation of Vietnamese Agriculture and Rural Society, Kagoshima University, Japan, 14-16 March 2011.

Nguyen, D. C., Duong, L. T., Nguyen, V. S., and Miller, F., 2007. Livelihoods and resource use strategies of farmers in the Mekong Delta. In T. B. Tran, T. S. Bach, and F. Miller, eds. Challenges to Sustainable Development in the Mekong Delta, pp. 66-98. Bangkok: Sustainable Mekong Research Network.

Nguyen, D. C., Sebesvari, Z., Amelung, W., and Renaud, F. G., 2015. Pesticide pollution of multiple drinking water sources in the Mekong Delta, Vietnam: evidence from two provinces. Environmental Science and Pollution Research. https://doi.org/10.1007/s11356-014-4034-x.

Nguyen, V. K., 2014. An Economic Evaluation of Flood Dike Construction in the Mekong Delta: Cost-Benefit Analysis of Flood Protection Dike Construction in An Giang Province. Lambert Academic Publishing.

Nguyen, V. K., and Howie, C. (eds.), 2018. Conservation and Development of the Floating Rice Based Agro-Ecological Farming Systems in the Mekong Delta. Hanoi: Agricultural Publishing House. 
Nguyen, V. K., and Huynh, D. N., 2015. Conserving the benefits of floating rice in Vietnam. Available at http://www.mekongcommons.org/conserving-thebenefits-of-floating-rice-in-viet-nam/ (accessed 28 March 2015).

Nguyen, V. K., and Pittock, J., 2016. Scoping floating rice-based agro-ecological farming systems for a healthy society and adaptation to climate change in the lower Mekong Region and Myanmar. Canberra: Australian National University.

Nguyen, V. K., Dumaresq, D., and Howe, C., 2016. Dike compartments: case studies in water governance, farming systems, and adaptation to water-regime changes in An Giang Province, Mekong Delta, Vietnam. In Dynamics of Water Governance in the Mekong Region. Mekong Program on Water, Environment and Resilience (M-POWER) Series, vol. 5. Kuala Lumpur: Strategic Information and Research Development Centre.

Nguyen, V. K., Dumaresq, D., and Pittock, J., 2018. Impacts of rice intensification on rural households in the Mekong Delta: emerging relationships between agricultural production, wild food supply and food consumption. Food Security 10: 1615-1629.

Phạm Thị Thúy Hạnh, and Furukawa, M., 2007. Impact of sea-level rise on coastal zone of Vietnam. Bulletin of the Faculty of Science, University of the Ryukyus 48: 45-59.

Preston, N., and Clayton, H., 2003. Rice-Shrimp Farming in the Mekong Delta: Biophysical and Socioeconomic Issues. Canberra: Australian Centre for International Agricultural Research (ACIAR).

Rothuis, A., 1998. Rice-Fish Culture in the Mekong Delta, Vietnam: Constraint Analysis and Adaptive Research. Leuven, Belgium: Katholieke Universiteit.

Stewart-Koster, B., Anh, N. D., Burford, A., Condon, J., Qui, N. V., Hiep, L. H., et al., 2017. Expert-based model building to quantify risk factors in a combined aquaculture-agriculture system. Agricultural Systems 157: 230-240.

Thang, T. C., 2017. Current Status of Vietnam Rice Export Quality. Taipei: Food and Fertilizer Technology Center for the Asian and Pacific Region.

Thuy, N. N., and Anh, H. H., 2015. Vulnerability of rice production in Mekong River Delta under impacts from floods, salinity and climate change. International Journal on Advanced Sciences Engineering and Technology 5(4): 272-279.

Tong, Y. D., 2017. Rice intensive cropping and balanced cropping in the Mekong Delta, Vietnam: economic and ecological considerations. Ecological Economics 132: 205-212.

USAID, 2016. Development of Rice-Shrimp Farming in Mekong River Delta, Vietnam. Washington, DC: United States Agency for International Development.

Vo, X. T., 1975. Rice cultivation in the Mekong Delta: present situation and potentials for increased production. Southeast Asian Studies 13(1): 88-111. 
Vormoor, K., 2010. Water Engineering, Agricultural Development and SocioEconomic Trends in the Mekong Delta, Vietnam. ZEF Working Paper Series No. 57. Bonn: Center for Development Research (ZEF), University of Bonn.

Wan, X.-F., Nguyen, T., Davis, C. T., Smith, C. B., Zhao, Z.-M., Carrel, M., et al., 2008. Evolution of Highly Pathogenic H5Nl Avian Influenza Viruses in Vietnam between 2001 and 2007. PLoS ONE 3(10): 1-12.

White, Ian, 2002. Water Management in the Mekong Delta: Changes, Conflicts and Opportunities. Technical Documents in Hydrology No. 61. Paris: UNESCO.

Xuan, V. T., and Matsui, S. (eds.), 1998. Development of Farming Systems in the Mekong Delta of Vietnam. Ho Chi Minh City: Ho Chi Minh City Publishing House.

Yasuyuki, K., 2001. Canal development and intensification of rice cultivation in the Mekong Delta: a case study in Cantho Province, Vietnam. Southeast Asian Studies 39(1): 70-85.

Open Access This chapter is licensed under the terms of the Creative Commons Attribution 4.0 International License (http://creativecommons.org/licenses/ by $/ 4.0 /$ ), which permits use, sharing, adaptation, distribution and reproduction in any medium or format, as long as you give appropriate credit to the original author(s) and the source, provide a link to the Creative Commons licence and indicate if changes were made.

The images or other third party material in this chapter are included in the chapter's Creative Commons licence, unless indicated otherwise in a credit line to the material. If material is not included in the chapter's Creative Commons licence and your intended use is not permitted by statutory regulation or exceeds the permitted use, you will need to obtain permission directly from the copyright holder.

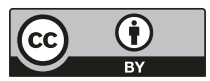

